\title{
Granulosa cell steroidogenesis and follicular fluid steroid concentrations after the onset of oestrus in cows*
}

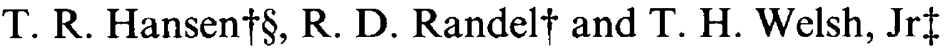 \\ $\uparrow$ Texas Agricultural Experiment Station, Texas A\&M University, Agricultural Research and \\ Extension Center, Overton, Texas 75684, U.S.A. and $\ddagger$ Physiology of Reproduction and Growth \\ Section, Department of Animal Science, Texas A\&M University, College Station, Texas 77843, \\ U.S.A.
}

\begin{abstract}
Summary. Granulosa cell responsiveness at an early ( $1-2 \mathrm{~h})$ or late (14-16 h) stage of differentiation following the onset of oestrus [and presumably the LH surge] was studied in 16 cows. Follicular fluid collected at the early stage ( 8 preovulatory follicles) had a higher concentration of testosterone $(P<0.05)$, oestradiol $(P<0.01)$ and oestrone $(P<0.01)$ than did follicular fluid collected at the late stage of oestrus $(8$ preovulatory follicles). No difference in follicular fluid progesterone was noted between follicles collected at the early and late stages of oestrus. Granulosa cells collected at the early stage of oestrus had a higher in-vitro response (progesterone production) to $\mathrm{LH}$ $(P<0.05)$, forskolin $(P<0.08)$ and diacylglycerol $(P<0.05)$ than did granulosa cells collected at the late stage of oestrus. However, later stage granulosa cells produced more $(P<0.01)$ progesterone after culture with prostaglandin E-2 than did earlier stage granulosa cells. These results show that follicular fluid oestrogen decreases, which suggests a loss of aromatase activity as oestrus progresses, and that granulosa cells become refractory (low progesterone production) to in-vitro LH, forskolin, and diacylglycerol challenge, yet acquire responsiveness to prostaglandin E-2 as oestrus progresses.
\end{abstract}

Keywords: cow; granulosa cells; LH; ovary; progesterone

\section{Introduction}

Bovine granulosa cells progress through a proliferative replicative stage in small follicles followed by a differentiation stage (i.e. acquisition of steroidogenic ability, hormone receptors) in large follicles (Gospodarowicz \& Bialecki, 1979). Eventually, granulosa cells of the dominant follicle progress through a terminal differentiation stage (luteinization). Terminal differentiation of granulosa cells involves both functional and morphological changes that require co-ordinated actions of several hormones (principally luteinizing hormone $(\mathrm{LH})$ ) and their intracellular second messengers.

The largest follicle present in the ovary of cows during the 2-3 days before ovulation has been identified as the preovulatory follicle (Dufour et al., 1972). In the present study, the ovary with the largest follicle was collected surgically at two stages of the terminal follicular differentiation process: (1) 1-2 h after the onset of oestrus when serum LH concentrations were high; and (2) 14-16 h after the onset of oestrus when serum $\mathrm{LH}$ concentrations were low. It was then possible to assess the response of preovulatory granulosa cells to stimulation with LH, prostaglandin E-2, prostaglandin F-2 $\alpha$, forskolin and diacylglycerol in vitro.

\footnotetext{
*Reprint requests to Dr R. D. Randel.

§resent address: 158 Animal Sciences Center, Molecular Biology Section, Department of Animal Science, University of Missouri, Columbia, Missouri 65211, U.S.A.
} 


\section{Materials and Methods}

Animal care and detection of oestrus. Non-lactating and cyclic cows (Angus $\times$ Hereford, Senepol $\times$ Hereford and Simmental $\times$ Hereford) from the experimental herd were managed as a group and housed in a paddock with access to coastal bermuda grass hay, cottonseed hulls and trace mineralized salt. Epididymectomized bulls equipped with marker devices were used in conjunction with visual observation at 2-h intervals throughout the daylight hours for detection of oestrus. When an animal showed signs of oestrus she was watched continuously to determine the onset of oestrus. The preliminary signs of oestrus utilized were mucous discharge, mounting behaviour and association with the bulls.

The timing of events associated with oestrus in cows has been reported (Dieleman et al., 1983; Randel, 1984): duration of oestrus was $\sim 18 \mathrm{~h}$; onset of the preovulatory LH surge was $\sim 0-5 \mathrm{~h}$ after onset of oestrus; and ovulation was $\sim 26-34 \mathrm{~h}$ after onset of oestrus. Cows were assigned to an early ( $1-2 \mathrm{~h}$; Group E; N $=8)$ or late (14-16 h; Group $L ; N=8$ ) stage after the onset of oestrus.

Collection of ovary and isolation of granulosa cells. The ovary with the largest follicle was removed via midflank laparotomy, under local anaesthesia. Three blood samples were collected at 10-min intervals during surgical collection of the ovary to determine serum LH concentrations. Ovaries collected at $1-2 \mathrm{~h}$ after the onset of oestrus had been exposed to at least a portion of the LH surge (as determined by LH radioimmunoassay) and were considered to be from an early stage of differentiation. Ovaries collected at $14-16 \mathrm{~h}$ after the onset of oestrus had been exposed (presumably) to the entire LH surge and were considered to be from a later stage of differentiation, albeit before ovulation.

Sterile techniques were utilized in vitro. The ovary was rinsed 5 times with wash medium which consisted of Medium 199 (GIBCO, Grand Island, NY), Hepes buffer (20 mM: GIBCO), deoxyribonuclease (20 Kunitz units/ml: CalBiochem, La Jolla, CA) and sodium heparin $(50 \mathrm{U} / \mathrm{ml}$ : United States Biochemical Corp., Cleveland, OH). Follicle diameter was recorded. Follicular fluid was aspirated with a $1-\mathrm{ml}$ syringe and a 26-gauge needle, and the volume of fluid was recorded. Follicular fluid was centrifuged $(2000 \mathrm{~g})$ to remove debris and the supernatant was stored $\left(-20^{\circ} \mathrm{C}\right)$ in plastic $12 \times 75 \mathrm{~mm}$ test tubes (Fisher Scientific, Plano, TX).

The volume of follicular fluid removed was replaced with wash medium to aid subsequent removal of granulosa cells. The follicle wall was opened with a scalpel blade to expose clumps of granulosa cells. Granulosa cells were rinsed out of the follicle into a $10 \times 35 \mathrm{~mm}$ Petri dish (Fisher Scientific) by gently scraping the follicle with a plastic pipette tip, while dispensing wash medium ( 4 rinses at $\sim 4 \mathrm{ml} /$ rinse). Granulosa cells were transferred to $15-\mathrm{ml}$ plastic tubes (Fisher Scientific) and centrifuged $(200 \mathrm{~g})$. The pellets of cells were combined into a single tube, wash medium was replaced with culture medium (Medium 199, Hepes buffer $(20 \mathrm{~mm})$ and granulosa cells were centrifuged $(200 \mathrm{~g})$ followed by resuspension with culture medium to yield a final culture concentration of 40000 viable cells $/ \mathrm{ml}$. Trypan blue exclusion was used to determine cell viability (mean \pm s.e.: $40 \cdot 3 \pm 2 \cdot 3 \%$ ).

Granulosa cells were cultured in an atmosphere of $95 \%$ air and $5 \% \mathrm{CO}_{2}$ for $48 \mathrm{~h}$ at $37^{\circ} \mathrm{C}$ in multiwell plates (surface area per well $=2.0 \mathrm{~cm}^{2}$; Fisher Scientific). The $48 \mathrm{~h}$ time of culture was selected based on previous reports for the rat (Hsueh et al., 1984) of maximal progesterone production by $48 \mathrm{~h}$. Also, in this study, a preliminary time-course experiment indicated that granulosa cell production of progesterone was maximal by $48-72 \mathrm{~h}$ in culture. Penicillin $(10000 \mathrm{U} / \mathrm{ml})$ streptomycin $(10000 \mu \mathrm{g} / \mathrm{ml})$ and glutamine $(200 \mathrm{~mm}$ : GIBCO) were prepared $(1: 1)$ and $10 \mathrm{ml}$ were added to $490 \mathrm{ml}$ medium. Fetal calf serum (GIBCO) was added to the medium (10\%), was from one batch (No. 27P4650) and had the following hormone concentrations: LH $(5 \mathrm{pg} / \mathrm{ml})$, progesterone $(6 \mathrm{pg} / \mathrm{ml})$, testosterone $(16 \mathrm{pg} / \mathrm{ml})$ and oestradiol $(8 \mathrm{pg} / \mathrm{ml})$.

In-vitro treatments were as follows: (1) control (medium alone); (2) LH (USDA-bLH-B-5; $2 \cdot 1 \mathrm{~S} 1 \mathrm{U} / \mathrm{ml}: 1,3,10$, 30,50 or $100 \mathrm{ng} / \mathrm{ml}$; National Hormone and Pituitary Program, National Institutes of Arthritis, Diabetes and Digestive and Kidney Diseases, Baltimore, MD); (3) forskolin ( $7 \beta$-acetoxy-8,13-epoxy-1 $\alpha, 6 \beta, 9 \alpha$-trihydroxy-labd-14ene-11-one: $5 \times 10^{-7}, 10^{-6}, 5 \times 10^{6}, 10^{-5}, 5 \times 10^{-5}$ or $10^{-4} \mathrm{M}$; Behring Diagnostics, La Jolla, CA); (4) prostaglandin (PG) F-2 $\alpha(0 \cdot 01,0 \cdot 1,1,10,100$, or $1000 \mathrm{ng} / \mathrm{ml}$; Upjohn Diagnostics, Kalamazoo, MI): (5) PGE-2 (0.01, 0.1, 1, 10,100 or $1000 \mathrm{ng} / \mathrm{ml}$ : Upjohn Diagnostics); or (6) diacylglycerol (1,2-dioctanoyl-glycerol; $10^{-7}, 10^{-6}, 5 \times 10^{-6}$, $10^{-5}$ or $10^{-4} \mathrm{M}$ : Life Sciences Resources, Milwaukee, WI). The broad ranges of in-vitro treatment doses were selected to encompass physiological levels as well as to accommodate variations in responses by individual cows. Androstenedione $\left(10^{-6} \mathrm{M}\right.$ : Steraloids, Inc., Wilton, NH) was added as substrate for aromatase. Androstenedione was added only to cultures designated for oestrogen production (i.e. cultures designated for progesterone production did not contain exogenous androstenedione). Four culture wells for each in-vitro treatment were used for each follicle from each cow from both stages after oestrus.

Radioimmunoassay. LH concentrations were determined by radioimmunoassay (Golter $e t$ al., 1973) as modified for use in our laboratory by Harrison \& Randel (1986). Rabbit anti-ovine LH was used (RAOLH, TEA \#35) as first antibody (J. J. Reeves, Washington State University, Pullman). Sheep anti-rabbit gamma globulin was purchased from Antibodies, Inc. (Davis, CA) and was used as second antibody. The intra-assay coefficient of variation was $10 \%$. Progesterone (Abraham et al., 1971), oestradiol-17ß (Korenman et al., 1974), oestrone (Horne et al., 1983) and testosterone (Murdoch \& Dunn, 1982) were measured by radioimmunoassays using procedures validated for our laboratory by Harrison et al. (1985). All steroid antisera were purchased from G. D. Niswender (Colorado State University, Fort Collins). The oestradiol-17 $\beta$ antibody (GDN 244 ) cross-reacts $2.6 \%$ with oestrone and $0.02 \%$ with testosterone. The oestrone antibody (GDN 325) cross-reacts $<1 \%$ with oestriol and oestradiol. The progesterone 
antibody (GDN 337) cross-reacts $1 \cdot 1 \%$ with pregneneolone, $0 \cdot 3 \%$ with oestrone, $0.3 \%$ with oestradiol, $0 \cdot 2 \%$ with testosterone and $0.2 \%$ with androstenedione. The intra-assay coefficients of variation for the oestradiol, oestrone and progesterone assays were $7 \cdot 3,3 \cdot 5$ and $8.9 \%$, respectively (all samples were analysed within the same assay).

Follicular fluid was assessed directly for steroid hormones since results are comparable for extracted and chromatographed follicular fluid (Ireland \& Roche, 1982, 1983). Granulosa cell media were also assessed directly for steroid hormones. The intra-assay coefficients of variation for the follicular fluid oestradiol, oestrone, testosterone and progesterone assays were $3 \%, 4 \%, 6 \%$ and $11 \%$, respectively. Sensitivities for $\mathrm{LH}$ and steroid assays were $0 \cdot 2 \mathrm{ng}$ and $10 \mathrm{pg}$, respectively.

Statistical analysis. Data were subjected to analysis of variance procedures and treatment differences determined by preplanned mean comparisons using Student's $t$ test (SAS, Inc., 1985). Because of the variation amongst cows, granulosa cell steroid accumulation was analysed as the proportion of basal release.

\section{Results}

Serum luteinizing hormone

Cows in Group E had higher $(P<0.0001)$ serum $\mathrm{LH}$ concentrations $(14 \pm 5 \cdot 1 \mathrm{ng} / \mathrm{ml})$ than did cows in Group L $(3 \cdot 1 \pm 0.6 \mathrm{ng} / \mathrm{ml})$.

\section{Follicular characteristics}

No difference in follicle diameter, follicular fluid volume, total number of granulosa cells, number of live granulosa cells or \% viable granulosa cells was evident between cows in Groups $\mathrm{E}$ and $\mathrm{L}$ (pooled mean: $13.1 \pm 0.7 \mathrm{~mm}, 1.4 \pm 0.2 \mathrm{ml}, 13.4 \pm 1.7 \times 10^{-6}, 5.4 \pm 0.7 \times 10^{6}$, $40 \cdot 3 \pm 2 \cdot 3 \%$; respectively). Follicular fluid collected from Group $E$ cows had higher oestradiol $(P<0.01)$, oestrone $(P<0.01)$ and testosterone $(P<0.05)$ concentrations than did follicular fluid collected from Group L cows (Table 1). No difference in progesterone concentrations was noted.

Table 1. Steroid hormone concentrations $(\mathrm{ng} / \mathrm{ml})$ in follicular fluid at an early (1-2 h, Group E) or late (14-16 h, Group L) stage after the onset of oestrus in cows

\begin{tabular}{lcc}
\hline Steroid & Group E & Group L \\
\hline Oestradiol & $798 \cdot 0 \pm 179 \cdot 1$ & $256 \cdot 3 \pm 75 \cdot 6^{* *}$ \\
Oestrone & $56 \cdot 4 \pm 10 \cdot 8$ & $19 \cdot 5 \pm 3 \cdot 5^{* *}$ \\
Testosterone & $15 \cdot 4 \pm 4 \cdot 1$ & $5 \cdot 1 \pm 1 \cdot 5^{*}$ \\
Progesterone & $58 \cdot 0 \pm 4 \cdot 1$ & $41 \cdot 1 \pm 4 \cdot 8$ \\
\hline
\end{tabular}

Values are means \pm s.e.m. with 8 cows/group.

${ }^{*} P<0.05,{ }^{* *} P<0.01$ compared with Group $\mathrm{E}$ value.

\section{Granulosa cell progesterone production}

Basal (no in-vitro treatment; control) granulosa cell progesterone production averaged $30.9 \mathrm{ng} / \mathrm{ml}$ and did not differ in follicles from cows in Groups $\mathrm{E}$ and $\mathrm{L}$.

Group E granulosa cells produced more $(P<0.05)$ progesterone $(25 \pm 4 \%$ over basal $)$ after culture with $\mathrm{LH}$ than did those from Group L cows (12 $\pm 4 \%$ over basal: Fig. 1a). The highest progesterone production over basal (43\%) was noted after culture of Group E granulosa cells with $100 \mathrm{ng} \mathrm{LH}$. Other doses of LH stimulated granulosa cell progesterone production to an equivalent degree.

All doses of forskolin stimulated production of progesterone in both groups of granulosa cells. Progesterone production after culture with forskolin tended to be higher $(P<0.08)$ for Group $\mathrm{E}$ 

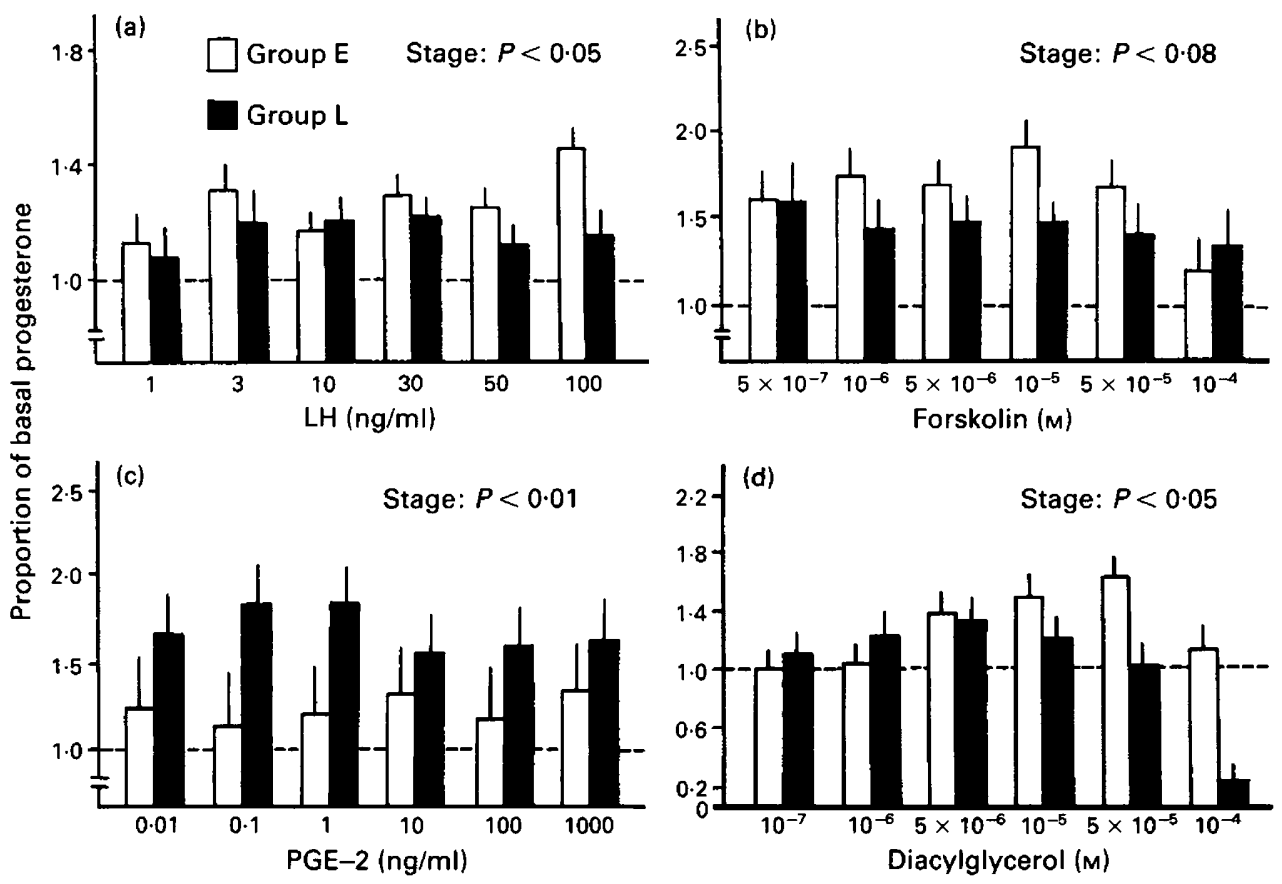

Fig. 1. Granulosa cell progesterone production at early (1-2 h, Group E) and late (14-16 h, Group L) stages after the onset of oestrus following culture with (a) LH, (b) forskolin, (c) PGE2 and (d) diacylglycerol. Granulosa cells were cultured for $48 \mathrm{~h}$ in medium alone (basal $=1 \cdot 0$ ) or with increasing concentrations of the test substance. Values represent the proportion of basal release (mean \pm s.e.m.) for 4 in-vitro replicates representing 8 cows (i.e. 8 follicles) from each stage after the onset of oestrus.

( $62 \pm 7 \%$ over basal) than for Group L ( $44 \pm 7 \%$ over basal) granulosa cells (Fig. 1b). Culture with a high level $\left(10^{-4} \mathrm{M}\right)$ of forskolin, however, resulted in a decline in progesterone production by Group E granulosa cells.

Granulosa cells from Groups $\mathrm{E}$ and $\mathrm{L}$ increased $(P<0.05)$ progesterone production above basal levels for each dose of PGF-2 $\alpha(0 \cdot 01-1000 \mathrm{ng} / \mathrm{ml})$, but the stimulatory effect did not appear to be dose-related. Additionally, progesterone production in response to PGF- $2 \alpha$ treatment did not differ $(P>0 \cdot 10)$ in the two groups. In contrast, granulosa cells from Group $L$ produced more $(68 \pm 10 \%$ over basal) progesterone $(P<0.01)$ after culture with $P G E-2$ than did granulosa cells from Group E $(24 \pm 13$ over basal; Fig. 1c). The highest progesterone production ( $82-83 \%$ over basal) was observed after culture with 0 1-1 ng PGE-2 of granulosa cells from Group L.

When compared over each dose of diacylglycerol (Fig. 1d), progesterone production differed $(P<0.05)$ by stage after oestrus. Group $\mathrm{E}$ granulosa cells exhibited a dose-dependent $(P<0 \cdot 05)$ increase in progesterone with $10^{-7}$ to $5 \times 10^{-5} \mathrm{M}$-diacylglycerol, followed by a decline $(P<0.06)$ to near basal levels at $10^{-4} \mathrm{M}$-diacylglycerol. Group $\mathrm{L}$ granulosa cells exhibited a slight increase in progesterone production with $10^{-7}$ to $5 \times 10^{-6} \mathrm{M}$-diacylglycerol, followed by a dosedependent $(P<0.01)$ decline to progesterone production that was $82 \%$ below basal levels at $10^{-4} \mathrm{M}$-diacylglycerol.

\section{Granulosa cell oestrogen production}

Cultures for oestrogen production included androstenedione $\left(10^{-6} \mathrm{M}\right)$ substrate for aromatization. Basal oestrone production was not different between Group E $(179 \pm 14 \mathrm{pg} / \mathrm{ml})$ and Group L 
$(161 \pm 10 \mathrm{pg} / \mathrm{ml})$ granulosa cells. Basal oestradiol, however, was higher $(P<0.01)$ in Group $\mathrm{E}$ $(765 \pm 139 \mathrm{pg} / \mathrm{ml})$ than in Group L $(238 \pm 48 \mathrm{pg} / \mathrm{ml})$ granulosa cells. Neither LH nor forskolin stimulated granulosa cell oestradiol or oestrone production over basal levels.

\section{Discussion}

Ovaries with the preovulatory follicle were collected early (1-2 h) or late (14-16 h) after the onset of oestrus to develop a source of granulosa cells from follicles at different stages of differentiation. Values for follicle diameter, follicular fluid volume, granulosa cell number and percentage viable granulosa cells were consistent with data provided by McNatty et al. (1984). The lack of an increase in granulosa cell numbers between follicles collected at $1-2 \mathrm{~h}$ when compared with $14-16 \mathrm{~h}$ after the onset of oestrus was consistent with the concept that terminally differentiated granulosa cells do not divide and multiply (Gospodarowicz \& Bialecki, 1979).

Oestradiol, oestrone and testosterone concentrations were higher in fluid collected from early than late stage follicles. The decreased ability to synthesize and secrete oestrogens has been previously documented in terminally differentiating follicles in the cow (Henderson \& Moon, 1979; Dieleman et al., 1983; Dieleman \& Blankenstein, 1984). Aromatase activity decreases, whereas progesterone synthesis increases as bovine granulosa cells luteinize in culture (Henderson \& Moon, 1979). Dieleman \& Blankenstein (1985) indicated that steroid synthesis in bovine preovulatory follicles changed from oestradiol production (inhibition of aromatase by $14 \mathrm{~h}$ after the LH peak) to progesterone production ( $20 \mathrm{~h}$ after the $\mathbf{L H}$ peak) as ovulation approached. Fortune \& Hansel (1985) suggested that follicular fluid progesterone concentrations did not differ between 15 and $24 \mathrm{~h}$ after the onset of oestrus. No difference in fluid progesterone concentration was noted between early $(1-2 \mathrm{~h})$ and late $(14-16 \mathrm{~h})$ stage follicles in the present study.

The number of $\mathrm{LH}$ receptors in rat granulosa cells increases as follicles mature (Richards, 1980). England et al. (1981) reported high LH/hCG receptor concentrations in sheep granulosa cells before the LH surge and a decline in receptors after the LH surge. In the present study, LH stimulated progesterone production in vitro to a greater degree in granulosa cells collected at the early when compared with the late stage after oestrus. This may have been due to a loss of receptors following the LH surge in vivo (down regulation) in the late granulosa cells and/or due to a desensitized adenylate cyclase system (Podesta et al., 1986).

Forskolin has been used in rat granulosa cell culture systems to study gonadotrophin-cyclic AMP-associated aspects of steroidogenesis and hormone receptor acquisition during differentiation (Adashi \& Resnick, 1984; Welsh et al., 1984a). In this study, low doses of forskolin initially stimulated progesterone production, which was followed by a dose-dependent (high doses) decline in progesterone production in early granulosa cells. Welsh et al. (1984a) observed a similar biphasic pattern of initial stimulation followed by inhibition at higher doses of forskolin in cultured rat granulosa cells. In the present study, forskolin stimulated progesterone production at both stages after oestrus. However, early granulosa cells produced more progesterone than did late granulosa cells in response to forskolin. This may indicate that the adenylate cyclase system was more responsive in granulosa cells collected at the early stage after oestrus. Furthermore, this suggests that the lowered response to $\mathrm{LH}$ in granulosa cells collected at the late stage after oestrus was not only due to possible down regulation of $\mathrm{LH}$ receptors, but also to a desensitized adenylate cyclase system.

Phospholipid turnover in cell membranes provides the major precursor (arachidonic acid) for prostaglandin biosynthesis. A local source of prostaglandins exists for follicular functions in the cow (Shemesh \& Hansel, 1975) and prostaglandins E and F have been detected in bovine preovulatory follicles (Hsueh et al., 1984). When human granulosa cells were pre-treated with $\mathrm{LH}$ and FSH, PGF-2 $\alpha$ had no effect on progesterone production (McNatty et al., 1975). Likewise, in the present study, PGF-2 $\alpha$ had no effect on progesterone production by bovine granulosa cells during early or late stages following the onset of oestrus. 
However, PGE-2 has actions similar to a luteotrophic hormone in that it stimulates progesterone production by rat follicles (Lindner et al., 1974) as well as monkey, pig and human granulosa cells (Channing \& Crisp, 1972; Kolena \& Channing, 1972; McNatty et al., 1975). Clark et al. $(1978,1979)$ speculated that the rise in follicular fluid prostaglandins in the rat was not only involved with the ovulatory process, but also with $\mathrm{LH}$-induced differentiation of the follicle. Consistent with a possible role in differentiation, PGE-2 stimulated progesterone production to a greater degree in granulosa cells collected during the late stage when compared with the early stage after onset of oestrus. Perhaps, as oestrus progresses, bovine granulosa cells acquire responsiveness to PGE-2. It remains to be determined whether PGE-2 receptors increase as granulosa cells differentiate.

Membrane phospholipid turnover has also been associated with signal tranduction and hormone action (Clark et al., 1985), as well as cell differentiation and proliferation (Michell, 1982). Diacylglycerol, a phospholipid metabolite, has been implicated as an activator of protein kinase-C, which requires calcium and phospholipid for activation, yet is cyclic AMP-independent. Shortterm culture of rat granulosa cells with phorbol esters (protein kinase-C activator; Kikkawa et al., 1983) stimulates progesterone accumulation (Kawai \& Clark, 1985), whereas long-term culture of rat granulosa cells with phorbol ester inhibits follicle-stimulating hormone and LH-stimulated steroidogenesis, and inhibits induction of LH receptors (Welsh et al., 1984b, 1985). The apparent stimulation of progesterone production in early and inhibition of progesterone production in late bovine granulosa cells by diacylglycerol (a protein kinase- $C$ activator) may reflect a change in phospholipid metabolism as well as protein kinase- $\mathrm{C}$ activation as oestrus and differentiation progress. The diversity of response following activation of protein kinase- $\mathrm{C}$ could be due, in part, to expression of different protein kinase-C mRNAs (Coussens et al., 1986) in early and late stage granulosa cells.

Aromatase activity decreases as a function of time in culture in bovine granulosa cells (Henderson \& Moon, 1979). Dieleman \& Blankenstein (1984) indicated that follicle wall aromatase activity declined after the LH surge and terminated at about $14 \mathrm{~h}$ following the LH surge. The low in-vitro output of oestrogens by the granulosa cells used in the present study may be explained by the stages of granulosa cell collection (1-2 $\mathrm{h}$ and $14-16 \mathrm{~h}$ after the onset of oestrus). Granulosa cells collected at the early stage produced more basal oestradiol (in vitro) than did granulosa cells collected at the late stage after oestrus. This difference in basal oestradiol secretion could be due to the degree of exposure (in vivo) to the preovulatory LH surge, and subsequent inhibition of aromatase activity as documented by Dieleman \& Blankenstein (1984).

In conclusion, oestrogen production by granulosa cells decreases after the LH surge. Also, granulosa cells become refractory to further in-vitro stimulation with LH and forskolin, which may encompass both receptor and adenylate cyclase function. And, most intriguing, is the stimulatory effect of PGE-2 on progesterone production by late stage cells, which may indicate that PGE-2 is involved in later stages of granulosa (oestrogen production) differentiation into luteal (progesterone production) cells.

We thank M. J. Guthrie, D. A. Neuendorff, R. W. Godfrey, R. P. Del Vecchio and A. M. Miller for technical assistance and Janis Williamson for typing the manuscript. This is Journal Series Paper TA 22543 of the Texas Agricultural Experiment Station. This study was a contribution to the Western Regional Research Project W-112, "Reproductive Performance in Domestic Ruminants".

\section{References}

Abraham, G.E., Swerdloff, R., Tulchinsky, D. \& Odell, W.D. (1971) Radioimmunoassay of plasma progesterone. J. clin. Endocr. Metab. 32, 619-624.
Adashi, E.Y. \& Resnick, C.E. (1984) Forskolin-induced differentiation of cultured rat granulosa cells: new evidence for an intermediary role of adenosine $3^{\prime}, 5^{\prime}$ - 
monophosphate in the mechanism of action of follicle-stimulating hormone. Endocrinology 115, 183-189.

Channing, C.P. \& Crisp, T.M. (1972) Comparative aspects of luteinization of granulosa cell cultures at the biochemical and ultrastructural levels. Gen. comp. Endocrinol. 3, 617-625.

Clark, M.R., Marsh, J.M. \& LeMaire, W.J. (1978) Mechanism of luteinizing hormone regulation of prostaglandin synthesis in rat granulosa cells. J. biol. Chem. 253, 7757-7761.

Clark, M.R., Marsh, J.M. \& LeMaire, W.J. (1979) The role of protein synthesis in the stimulation by $\mathrm{LH}$ of prostaglandin accumulation in rat preovulatory follicles in vitro. In Ovarian and Follicular Development and Function, pp. 255 - Eds A. R. Midgley \& W. A. Sadler, Raven Press, New York.

Clark, M.R., Kawai, Y., Davis, J.S. \& LeMaire, W.J. (1985) Ovarian protein kinases. In Proc. 5th Ovarian Workshop, pp. 383-401. Eds D. O. Toft \& R. J. Ryan. Ovarian Workshops, Champaign.

Coussens, L., Parker, P.J., Rhee, L., Yang-Feng, T.L., Chen, E., Watterfield, M.D., Francke, U. \& Ullrich, A. (1986) Multiple, distinct forms of bovine and human protein kinase $\mathrm{C}$ suggest diversity in cellular signaling pathways. Science, N.Y. 233, 859-866.

Dieleman, S.J. \& Blankenstein, D.M. (1984) Changes in oestrogen-synthesizing ability of preovulatory bovine follicles relative to the peak of LH. J. Reprod. Fert. 72, 487-494

Dieleman, S.J. \& Blankenstein, D.M. (1985) Progesteronesynthesizing ability of preovulatory follicles of cows relative to the peak of LH. J. Reprod. Fert. 75, 609-615.

Dieleman, S.J., Kruip, Th. A.M., Fontijne, P., de Jong, W.H.R. \& van der Weyden, G.C. (1983) Changes in oestradiol, progesterone and testosterone concentrations in follicular fluid and in the micromorphology of preovulatory bovine follicles relative to the peak of luteinizing hormone. J. Endocr. 97, 31-42.

Dufour, J., Whitemore, H.L., Ginther, O.J. \& Casida, L.E. (1972) Identification of the ovulating follicle by its size on different days of the estrous cycle in heifers. J. Anim. Sci. 34, 85-87.

England, B.G., Webb, R. \& Dahmer, M.K. (198l) Follicular steroidogenesis and gonadotropin binding to ovine follicles during the estrous cycles. Endocrinology 109, 881-887.

Fortune, J.E. \& Hansel, W. (1985) Concentrations of steroids and gonadotropins in follicular fluid from normal heifers and heifers primed for superovulation. Biol. Reprod. 32, 1069-1079.

Golter, T.D., Reeves, J.J., O'Mary, C.C., Arimura, A. \& Schally, A.V. (1973) Serum LH levels in bulls treated with synthetic luteinizing hormone-releasing hormone/follicle stimulating hormone-releasing hormone (LH-RH/FSH-RH). J. Anim. Sci. 37, 123-127.

Gospodarowicz, D. \& Bialecki, H. (1979) Fibroblast and epidermal growth factors are mitogenic agents for cultured granulosa cells of rodent, porcine and human origin. Endocrinology 104, 757-764.

Harrison, L.M. \& Randel, R.D. (1986) Influence of insulin and energy intake on ovulation rate, luteinizing hormone and progesterone in beef heifers. J. Anim. Sci. 63, 1228-1235.
Harrison, L.M., Randel, R.D., Forrest, D.W., Betts, J.G., Humphrey, W.D. \& Hardin, D.R. (1985) Cloprostenol induced luteal regression in the beef cow. I. Ovarian response and endocrine changes. Theriogenology 23, 511-521.

Henderson, K.M. \& Moon, Y.S. (1979) Luteinization of bovine granulosa cells and corpus luteum formation associated with loss of androgen aromatizing ability. J. Reprod. Fert. 56, 89-97.

Horne, C., Chew, B.P., Wiseman, B.S. \& Dziuk, P.J. (1983) Relationship between the level of estrone sulfate in the plasma and the number of fetuses during pregnancy in the gilt. Biol. Reprod. 29, 56-62.

Hsueh, A.J.W., Adashi, E.Y., Jones, P.B.C. \& Welsh, T.H., Jr (1984) Hormone regulation of granulosa cell differentiation. Endocr. Rev. 5, 76-127.

Ireland, J.J. \& Roche, J.F. (1982) Development of antral follicles in cattle after prostaglandin-induced luteoly. sis: changes in serum hormones, steroids in follicular fluid and gonadotropin receptors. Endocrinology 111, 2077-2086.

Ireland, J.J. \& Roche, J.F. (1983) Development of nonovulatory antral follicles in heifers: changes in steroids in follicular fluid and receptors for gonadotropins. Endocrinology 112, 150-156.

Kawai, Y. \& Clark, M.R. (1985) Phorbol ester regulation of rat prostaglandin and progesterone accumulation. Endocrinology 116, 2320-2326.

Kikkawa, U., Takai, Y., Tanaka, Y., Miyake, R. \& Nishizuka, Y. (1983) Protein kinase $C$ as a possible receptor protein of tumor-promoting phorbol esters. J. biol. Chem. 258, 11442-11445.

Kolena, J. \& Channing, C.P. (1972) Stimulatory effects of LH, FSH and prostaglandins upon cyclic 3,5-AMP levels in porcine granulosa cells. Endocrinology 90 , $1543-1550$.

Korenman, S.G., Stevens, R.H., Carpenter, L.A., Robb, M., Niswender, G.D. \& Sherman, B.M. (1974) Estradiol radioimmunoassay without chromatography: procedure, validation and normal values. $J$. clin. Endocr. Metab. 38, 718-720.

Lindner, H.R., Tsafriri, A., Lieberman, M.E., Zor, U., Koch, Y., Bauminger, S. \& Barnea, A. (1974) Gonadotrophin action on cultured Graafian follicles: induction of maturation division of the mammalian oocyte and differentiation of the luteal cell. Recent Prog. Horm. Res. 30, 79-138.

MeNatty, K.P., Heath, D.A., Lun, S., Fannin, J.M., McDiarmid, J.M. \& Henderson, K.M. (1984) Steroidogenesis by bovine theca interna in an in vitro perifusion system. Biol. Reprod. 30, 159-170.

McNatty, K.P., Henderson, K.M. \& Sawers, R.S. (1975) Effects of prostaglandin $\mathrm{F}_{2 a}$ and $\mathrm{E}_{2}$ on the production of progesterone by human granulosa cells in tissue culture. J. Endocr. 67, 231-240.

Michell, R.H. (1982) Inositol lipid metabolism in dividing and differentiating cells. Cell Calcium 3, 429-440.

Murdoch, W.J. \& Dunn, T.G. (1982) Alteration in follicular steroid hormones during the preovulatory period in the ewe. Biol. Reprod. 27, 300-307.

Podesta, E.J., Solano, M.L. \& Sanchez, M.L. (1986) Luteinizing hormone triggers two opposite regulatory pathways through an initial common event, receptor aggregation. Endocrinology 119, 989-997.

Randel, R.D. (1984) Seasonal effects on female repro- 
ductive functions in the bovine (Indian breeds). Theriogenology 21, 170-185.

Richards, J.S. (1980) Maturation of ovarian follicles: Actions and interactions of pituitary and ovarian hormones on follicular cell differentiation. Physiol. Rev. 60, 51-89.

SAS Institute, Inc. (1975) SAS User's Guide: Statistics, 1985 edition. SAS Institute, Inc., Cary.

Shemesh, M. \& Hansel, W. (1985) Arachidonic acid and bovine corpus luteum function. Proc. Soc. exp. Biol. Med. 148, 243-246.
Welsh, T.H., Jr, Jia, X.-C. \& Hsueh, A.J.W. (1984a) Forskolin and phosphodiesterase inhibitors stimulate rat granulosa cell differentiation. Molec. cell Endocrinol. 37, 51-60.

Welsh, T.H., Jr, Jones, P.B.C. \& Hsueh, A.J.W. (1984b) Phorbol ester inhibition of ovarian and testicular steroidogenesis in vitro. Cancer Res. 44, 885-892.

Welsh, T.H., Jr, Hansen, T.R., Williams, D.J. \& Randel, R.D. (1985) Phorbol ester inhibition of steroidogenesis and LH-receptor acquisition in cultured granulosa cells. In Vitro Cell and Develop. Biol. 21, 55A, Abstr.

Received 8 December 1987 